\title{
Sodium-bearing phases in the transition zone and uppermost lower mantle: Experimental and natural data
}

\author{
Andrey V. Bobrov ${ }^{1,2,3}$, Anastasiya P. Tamarova1, Ekaterina A. Sirotkina ${ }^{1,2,3}$, Luca \\ Bindi $^{4}$ and Tetsuo Irifune ${ }^{5}$ \\ ${ }^{1}$ Moscow State University, Moscow, Russia, archi@geol.msu.ru, dragon.of.rainbow@yandex.ru \\ ${ }^{2}$ Vernadsky Institute of Geochemistry and Analytical Chemistry of Russian Academy of Sciences, Moscow, \\ Russia, skatty.ea@gmail.com \\ ${ }^{3}$ Institute of Experimental Mineralogy of Russian Academy of Sciences, Chernogolovka, Russia \\ ${ }^{4}$ Dipartimento di Scienze della Terra, Università di Firenze, Firenze, Italy, luca.bindi@ unifi.it \\ ${ }^{5}$ Geodynamics Research Center, Ehime University, Matsuyama, Japan, irifune@dpc.ehime-u.ac.jp
}

\section{Introduction}

$\mathrm{Na}$ is an incompatible element in the Earth's mantle and among the main hosts for sodium beneath the 410-km boundary are majoritic garnet (transition zone and upper part of the lower mantle), $\mathrm{CaSiO}_{3}$ perovskite and NaAl-phase $\left(\mathrm{NaAlSiO}_{4}\right)$ with the Ca ferrite-type structure (lower mantle).

Na-bearing majoritic garnets (up to $5.89 \mathrm{wt} \% \mathrm{Na}_{2} \mathrm{O}$; Kaminsky 2012) were discovered as inclusions in diamonds of the eclogitic assemblage in many regions worldwide including Kankan area in Guinea, West Africa, where majorite with the high sodium content $\left(1.37 \mathrm{wt} \% \mathrm{Na}_{2} \mathrm{O}\right)$ associated with potassiumrich clinopyroxene $\left(1.44 \mathrm{wt} \% \mathrm{~K}_{2} \mathrm{O}\right.$ ) (Stachel 2001). As is evident from the experimental data (Akaogi 2007), majorite may be stable under pressures of up to $28 \mathrm{GPa}$ (i.e., in the uppermost horizons of the lower mantle), and the concentrations of $\mathrm{Na}$ and $\mathrm{Si}$ in such garnets may be used for pressure estimation. In addition, Na-bearing majoritic garnet is compatible with sodium-rich alkaline silicate and carbonatesilicate melts produced by partial melting of the mantle material within the diamond depth facies (Bobrov et al. 2008).

Accessory lower mantle phases like $\mathrm{CaSiO}_{3}$-perovskite or $\mathrm{NaAl}$-phase can contain appreciable amounts of alkalis, but the mantle depleted from crust-extraction is expected to contain very low portions of these phases This opens the question, how can $\mathrm{Na}$ be transferred back into the lower mantle. Only 'refertilization' of mantle by subduction processes can provide these elements for lower mantle phases and form high-Na phases. Recently, nyerereite $\left(\mathrm{Na}_{2} \mathrm{Ca}\left(\mathrm{CO}_{3}\right)_{2}\right)$ and nahcolite $\left(\mathrm{NaHCO}_{3}\right)$ have been indentified in a specific lower mantle carbonatitic association (Juina area, Brazil) in association with typical lower mantle minerals, such as CaSi-perovskite and ferropericlase (Kaminsky 2012).

\section{Experimental techniques}

To study the crystal-chemical behavior of sodium in the deep Earth, we performed experiments on a simplified chemical system involving Na-rich carbonated melt and mantle silicate at $24 \mathrm{GPa}$ and 1100$1700^{\circ} \mathrm{C}$, thus representing the conditions at the border between the transition zone and lower mantle. Experiments were performed using a 2000 ton split-sphere press installed at the Ehime University (Matsuyama, Japan). A Co (17 wt\%)-doped $\mathrm{MgO}$ octahedral pressure medium of $8 \mathrm{~mm}$ edge length was compressed using eight cubic tungsten carbide anvils with $3 \mathrm{~mm}$ truncation edge lengths. Pyrophyllite gaskets, $4 \mathrm{~mm}$ in width, were used to seal the compressed volume and support the anvil flanks. Heating of the sample was performed by a cylindrical $\mathrm{LaCrO}_{3}$ heater, $3.2 / 2.0 \mathrm{~mm}$ in outer/inner diameter and $4 \mathrm{~mm}$ in length. Approximate sample volumes after experiments were $1.0 \mathrm{~mm}^{3}$. Starting mixtures of oxides and carbonate were dried for a few days at a temperature of $105{ }^{\circ} \mathrm{C}$ and kept in a dessicator. Temperature during the experiment was controlled by a $\mathrm{W}_{97} \mathrm{Re}_{3}-\mathrm{W}_{75} \mathrm{Re}_{25}$ thermocouple, $0.1 \mathrm{~mm}$ in diameter. The pressure was calibrated at room temperature using the semiconductor-metal transitions of $\mathrm{Bi}, \mathrm{ZnS}$, and $\mathrm{GaAs}$ (Irifune et al. 2004). The effect of temperature on pressure was further corrected using the $\alpha-\beta$ and $\beta-\gamma$ phase transitions of olivine (Katsura and Ito 1989). The run durations were 15-60 min. 


\section{Results}

In all samples, partial melting was registered: crystals of $\mathrm{Na}$-bearing $\mathrm{Al}, \mathrm{Fe}^{3+}$-bridgmanite occurred in microcrystalline carbonate-silicate quenched matrix; at $1300^{\circ} \mathrm{C}$, grains of $\mathrm{Na}_{2} \mathrm{Mg}\left(\mathrm{CO}_{3}\right)_{2}$ and $(\mathrm{Mg}, \mathrm{Fe}) \mathrm{O}$ grains were observed. With decreasing temperature melt composition evolved from silicate-carbonate to alkaline-carbonate. Bridgmanite contained $\mathrm{Al}_{2} \mathrm{O}_{3}$ (0.6-2.7 wt.\%), $\mathrm{Fe}_{2} \mathrm{O}_{3}$ (1.6-3.5 wt.\%), and up to 1.6 wt $\% \mathrm{Na}_{2} \mathrm{O}$ (at $1700^{\circ} \mathrm{C}$ ). There is a positive correlation between the concentration of sodium in bridgmanite and temperature (Figure 1).

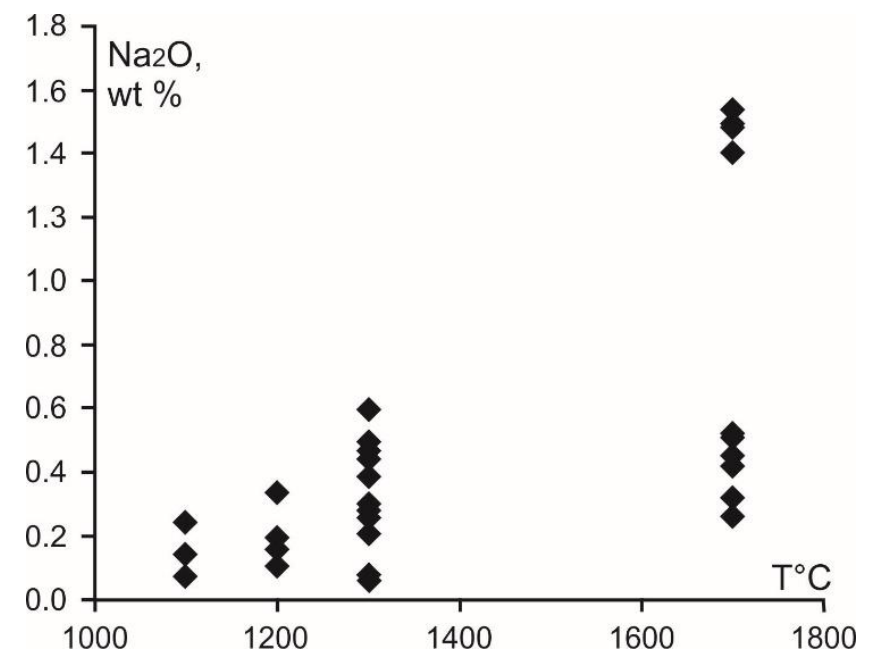

Figure 1: $\mathrm{Na}_{2} \mathrm{O}$ concentration in synthetic bridgmanites depending on temperature.

The unit-cell volume observed for Na-bearing bridgmanite (166(1) $\AA 3$ ) is larger than that observed for pure $\mathrm{MgSiO}_{3}$ (162.53(1) Å3, Dobson and Jacobsen 2004), due to the presence of the large Na cation. However, the mechanisms of $\mathrm{Na}$ incorporation in this structure remain unknown and require additional studies. As the chemical compositions obtained are not charge balanced, a probable solution could be a partial oxygen vacancy, as commonly observed in O-deficient perovskites (Akaogi 2007).

High-Na ringwoodite (up to $4.4 \mathrm{wt} \% \mathrm{Na}_{2} \mathrm{O}$ ) was obtained at $24 \mathrm{GPa}$ and $1700^{\circ} \mathrm{C}$ (Bindi et al 2016). The effect of $\mathrm{Na}$ in the ringwoodite structure is also apparent in the unit-cell parameter, which increases to 8.0952 (3) in Na-ringwoodite with respect to 8.0816 in pure $\mathrm{Mg}_{2} \mathrm{SiO}_{4}$ (Ye et al. 2012).

\section{Implications}

Our results have implications for transport of alkalis into the lower mantle of the Earth. Although the concentration of alkalis in the Earth's transition zone and lower mantle is low and $\mathrm{Na}$ remains incompatible in most of the high-pressure solid phases, it is expected that some mantle phases could act as important hosts for $\mathrm{Na}$, and perhaps $\mathrm{K}$, in the deep transition zone and lower mantle. In the model of Walter et al. (2008), melting occurs as slabs descend and stagnate in the transition zone, and heat up to the carbonated eclogite solidus where they release a low-degree melt. Such low-degree carbonatitic melts from eclogite are expected to be mobile and rich in alkali, and so may act as effective metasomatizing agents. The presence of such melts in the deep mantle is supported by inclusions of Nacarbonates [nyerereite $(\mathrm{Na}, \mathrm{K})_{2} \mathrm{Ca}\left(\mathrm{CO}_{3}\right)_{2}$ and eitelite $\mathrm{Na}_{2} \mathrm{Mg}\left(\mathrm{CO}_{3}\right)_{2}$ ] in lower mantle diamonds (Kaminsky et al. 2016) and incorporation of sodium in major mantle silicates, such as majoritic garnet ringwoodite, and bridgmanite.

In contrast, proper $\mathrm{Na}-\mathrm{Mg}$ silicates have not been registered as inclusions in diamonds or in mantle rocks, although they were obtained as products of experiments in many Na-rich model systems (Yang et al. 2009). This is explained by the fact that all natural lithologies are characterized by an excess of $\mathrm{Al}$ with respect to $\mathrm{Na}$. However, the finding of an inclusion in diamond with the composition $\left(\mathrm{Na}_{0.16} \mathrm{Mg}_{0.84}\right)\left(\mathrm{Mg}_{0.92} \mathrm{Si}_{0.08}\right) \mathrm{Si}_{2} \mathrm{O}_{6}$ in a Chinese kimberlite (Wang and Sueno, 1996) suggests that some local areas of the Earth's deep mantle previously involved in the mantle-crust interaction may be 
significantly enriched in Na. In this relation, study of Na-rich Mg-silicates will increase our knowledge on the composition and properties of the deep mantle.

\section{Acknowlwedgment}

This study was supported by the Russian Science Foundation (project no. 17-17-01169).

\section{References}

Akaogi M (2007) Phase transitions of minerals in the transition zone and upper part of the lower mantle, in Ohtani E, ed, Advances in high-pressure mineralogy: Geol Soc Amer Spec Paper 421:1-13

Bindi L, Tamarova A, Bobrov AV, Sirotkina EA, Tschauner O, Walter MJ, Irifune T (2016) Incorporation of high amounts of $\mathrm{Na}$ in ringwoodite: possible implications for transport of alkali into lower mantle. Am Miner 101:483-486

Bobrov AV, Litvin YuA, Bindi L, Dymshits AM (2008) Phase relations and formation of sodium-rich majoritic garnet in the system $\mathrm{Mg}_{3} \mathrm{Al}_{2} \mathrm{Si}_{3} \mathrm{O}_{12}-\mathrm{Na}_{2} \mathrm{MgSi}_{5} \mathrm{O}_{12}$ at 7.0 and $8.5 \mathrm{GPa}$. Contrib Mineral Petrol 156:243-257

Dobson DP and Jacobsen SD (2004) The flux growth of magnesium silicate perovskite single crystals. Am Miner 89:807-811

Kaminsky F (2012) Mineralogy of the lower mantle: A review of 'super-deep' mineral inclusions in diamond. Earth-Sci Rev 110:127-147

Stachel T (2001) Diamonds from the asthenosphere and the transition zone. Eur J Mineral 13:883-892

Walter MJ, Bulanova GP, Armstrong LS, Keshav S, Blundy JD, Gudfinnsson G, Gobbo L (2008) Primary carbonatite melt from deeply subducted oceanic crust. Nature 454:622-625

Wang W, Sueno S (1996) Discovery of a NaPx-En inclusion in diamond: Possible transition zone origin. Min Journal 18:9-16

Ye Y, Brown DA, Smyth JR, Panero WR, Jacobsen SD, Chang YY, Townsend JP, Thomas SM, Hauri EH, Dera P, Frost DJ (2012) Compressibility and thermal expansion of hydrous ringwoodite with 2.5(3) $\mathrm{wt} \% \mathrm{H}_{2} \mathrm{O}$. Am Miner 97:573-582 